\title{
Regulation of the carbohydrate metabolism in Lactococcus lactis and other lactic acid bacteria
}

\author{
Evert J. Luesink ${ }^{\mathrm{a}}$, Oscar P. Kuipers ${ }^{\mathrm{a} *}$, Willem M. de Vos ${ }^{\mathrm{a}, \mathrm{b}}$ \\ ${ }^{a}$ Microbial Ingredients Section, NIZO, P.O. Box 20,6710 BA, Ede, the Netherlands \\ ${ }^{b}$ Laboratory of Microbiology, Department of Biomolecular Sciences, Wageningen Agricultural \\ University, the Netherlands
}

\begin{abstract}
In recent years significant progress has been made in elucidating the regulation of carbohydrate metabolism in Lactococcus lactis and other lactic acid bacteria. Since insight in these mechanisms could provide valuable tools for metabolic engineering, an overview of the various global control systems in Gram-positive bacteria is presented with specific attention for inducer exclusion, inducer expulsion and catabolite repression. Inducer exclusion is the phenomenon where the addition of a rapidly metabolizable sugar like glucose to the medium results in a reduced uptake of other sugars. Under the same circumstances another system called inducer expulsion is active that reduces the intracellular concentration of sugar phosphates by dephosphorylating sugar phosphates and removing the sugars from the cell. Both mechanisms have been shown to depend on the phosphorylation state of residue serine 46 of the phosphocarrier HPr by a metaboliteactivated kinase. Apart from allosteric control, the carbohydrate metabolism can also be regulated at the transcriptional level. An example of transcriptional regulation is catabolite repression where the presence of a rapidly metabolizable sugar in the medium reduces the transcription of genes required for the utilization of other sugars. Gram-positive bacteria mediate catabolite repression via a transcriptional regulator, CcpA. To analyze the role of HPr and CcpA in the sugar metabolism in Lactococcus lactis, the genes encoding HPr and CcpA, ptsH and ccpA respectively, have been cloned and analyzed. (C) Inra/Elsevier, Paris.
\end{abstract}

\section{Lactococcus lactis / catabolite repression / carbohydrate metabolism / regulation}

Résumé - Régulation du métabolisme des sucres chez Lactococcus lactis et d'autres bactéries lactiques. Des progrès significatifs ont été réalisés au cours des dernières années pour élucider la régulation du métabolisme des sucres chez Lactococcus lactis et d'autres bactéries lactiques. Comme la connaissance de ces mécanismes constitue un outil précieux pour l'ingénierie métabolique, une vue d'ensemble des différents systèmes de contrôle globaux des bactéries Gram positives est présentée, avec une attention particulière portée à l'exclusion par l'inducteur, l'expulsion par l'inducteur et la répression catabolique. L'exclusion par l'inducteur correspond

*Correspondence and reprints. E-mail: Kuipers@ nizo.nl 
au phénomène où l'addition d'un sucre rapidement métabolisable comme le glucose dans le milieu résulte en une moindre consommation des autres sucres. Dans les mêmes circonstances, un autre système, appelé expulsion par l'inducteur est actif et réduit la concentration intracellulaire des sucres phosphorylés en les déphophorylant et en otant les sucres de la cellule. Les deux mécanismes sont dépendants de l'état de phosphorylation du résidu sérine-46 du phosphotransporteur HPr qui dépend d'une kinase activée par un métabolite. Outre un contrôle allostérique, le métabolisme des sucres peut aussi être régulé au niveau transcriptionnel. Un exemple de régulation transcriptionnelle est la répression catabolique où la présence d'un sucre rapidement métabolisable dans le milieu réduit la transcription des gènes requis pour l'utilisation des autres sucres. Les bactéries Gram positives expriment leur répression catabolique via un régulateur transcriptionnel, CcpA. Pour analyser le rôle de HPr et CcpA dans le métabolisme de Lactococcus lactis, les gènes codants pour $\mathrm{HPr}$ et $\mathrm{CcpA}$, ptsH et ccpA respectivement, ont été clonés et analysés. (C) Inra/Elsevier, Paris.

\section{Lactococcus lactis / répression catabolique / métabolisme des sucres / régulation}

\section{INTRODUCTION}

Lactic acid bacteria (LAB) are widely used for the production of a variety of fermented dairy products. Using a relatively simple metabolism these bacteria convert various sugars into lactate and other acids. The end products protect against spoilage and may contribute to the flavor of the final product. Insight in the regulatory mechanisms involved in the sugar catabolism of LAB could provide valuable tools for metabolic engineering [6].

Strains of $L$. lactis take up most sugars via the phosphotransferase system (PTS). The PTS catalyzes the uptake and phosphorylation of a sugar via a cascade of phosphotransfer proteins including HPr and enzyme I that must be phosphorylated at the expense of phosphoenolpyruvate (PEP). If a sugar is taken up via a permease the uptake step is followed by a phosphorylation step catalyzed by a sugar kinase. The product of both uptake systems is a phosphorylated sugar that can enter the central metabolism [7]. To prevent the accumulation of toxic intermediates such as phosphorylated sugars the central sugar metabolism needs to be regulated tightly. Accumulation can be prevented by the removal of such compounds from the cell or by regulating enzymatic activities that affect the concentration of these toxic intermediates. These enzymatic activities can be regulated allosterically or at the level of gene expression and in many cases combinations of these systems are operating. Here we will describe examples of relevant control systems in L. lactis and other LAB, with specific attention for global regulatory mechanisms.

\section{ALLOSTERIC CONTROL SYSTEMS INCLUDING INDUCER EXCLUSION AND INDUCER EXPULSION}

The early glycolytic intermediate fructose-1,6-diphosphate (FDP) is known to play an important role in the allosteric regulation of carbohydrate metabolism. The concentration of FDP and other early glycolytic intermediates increases when the glycolytic activity of the cell is high [19]. Allosteric regulation by FDP has been reported for pyruvate kinase (PK) and lactate dehydrogenase (LDH) $[1,2]$. Activation of PK and LDH can be seen as a detoxification process because an enhanced activity of these enzymes reduces the intracellular concentration of sugar phosphates. 
Apart from the phosphorylation of HPr at residue histidine 15 by enzyme I, a second phosphorylation site has been described that appears to be specific for Grampositive bacteria, including $L$. lactis. This phosphorylation at residue serine 46 is catalyzed by a protein kinase at the expense of ATP. The HPr kinase is activated by elevated concentrations of early glycolytic intermediates such as FDP [3, 4]. HPr phosphorylated on residue serine $46(\operatorname{HPr}(\operatorname{Ser}-\mathrm{P}))$ is a poor substrate for the catalytic phosphorylation on residue histidine 15 by enzyme I. Consequently, the FDP concentration modulates the activity of the PTS.
Inducer expulsion is a mechanism by which the cell can remove sugar phosphates from the cell. The sugar phosphates have to be dephosphorylated before leaving the cell via a so far unidentified mechanism. A cytoplasmic hexose-6-phosphate hydrolase from $L$. lactis has been purified and characterized that catalyzes the dephosphorylation of several sugar phosphates [20]. Since this hydrolase is constitutively produced and has a broad substrate range, it may play an important role in inducer expulsion. Recently, another membraneassociated hexose-6-phosphate hydrolase has been purified from $L$. lactis. The activity of this protein was activated 10 -fold by Ser46Asp-HPr that conformationally resembles $\operatorname{HPr}(\mathrm{Ser}-\mathrm{P})$ [23] (figure 1).

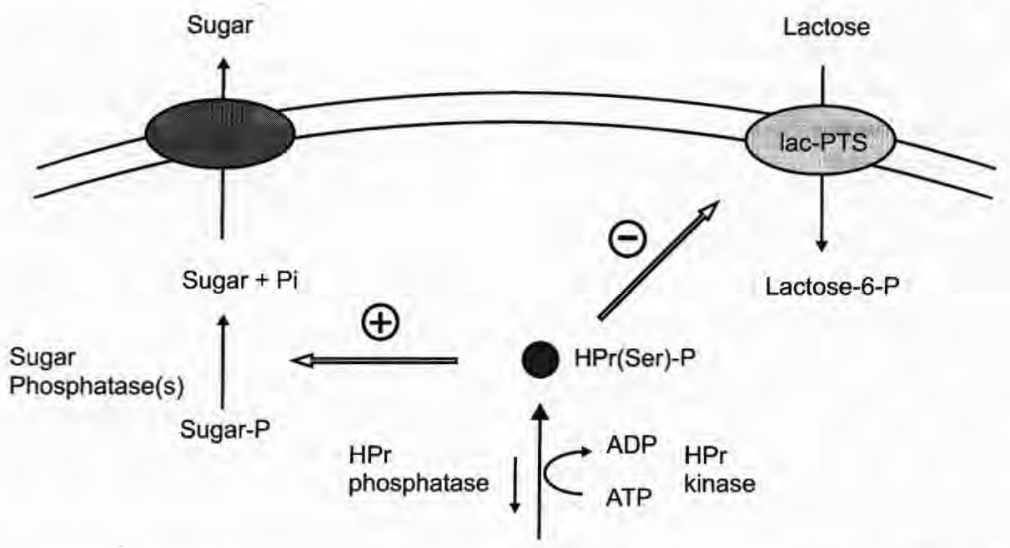

Inducer expulsion

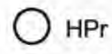

Inducer exclusion

Figure 1. A schematic presentation of the inducer exclusion and inducer expulsion mechanisms. An increased concentration of FDP activates a HPr kinase that phosphorylates HPr on residue serine 46. Inducer exclusion is mediated via an allosterical interaction of $\operatorname{HPr}(\operatorname{Ser} 46-\mathrm{P})$ with the lactosespecific Enzyme II which reduces the uptake of lactose. Inducer expulsion depends on the activation of a sugar-phosphate phosphatase by $\mathrm{HPr}(\mathrm{Ser}-\mathrm{P})$. The increased sugar phosphatase activity results in a dephosphorylation of sugar phosphates. The resulting sugars are removed from the cell via a sofar unidentified mechanism.

Figure 1. Présentation schématique des mécanismes de l'exclusion et de l'expulsion par l'inducteur. Une augmentation de la concentration en FDP active une HPr kinase qui phosphoryle HPr au niveau du résidu sérine-46. L'exclusion par l'inducteur est réalisée via une interaction allostérique de $\operatorname{HPr}$ (Ser46-P) avec l'enzyme II, lactose spécifique, qui réduit la consommation de lactose. L'expulsion par l'inducteur dépend de l'activation d'une phosphatase des sucres phosphorylés par HPr (Ser-P). L'augmentation de l'activité de la phosphatase des sucres résulte en la déphosphorylation des sucres phosphorylés. Les sucres résultants sont éliminés de la cellule par un mécanisme encore non identifié. 
Although vesicle studies revealed the functionality of this hydrolase, its overall contribution to inducer expulsion in $L$. lactis remains to be established.

Another example of allosteric control is inducer exclusion, a mechanism by which the cell can immediately reduce the uptake of a sugar upon the addition of a rapidly metabolizable carbon source to the medium (figure 1) The uptake of $\left[{ }^{14} \mathrm{C}\right] \mathrm{TMG}$, a lactose analog, via the lactose PTS in L. lac$t$ is is inhibited when glucose is added to the medium [22]. Membrane vesicles of L. lactis take up $\left[{ }^{14} \mathrm{C}\right] \mathrm{TMG}$ but the reduced uptake in the presence of glucose, as observed in intact cells, is not occurring. These findings indicated that cytoplasmic components play an important role in inducer exclusion. Electroporation of Bacillus subtilis HPr protein into the vesicles resulted in reconstitution of the reduced uptake in the presence of glucose [22], indicating that HPr is important in inducer exclusion. To investigate the role of the phosphorylation of HPr on residue serine 46 in inducer exclusion, a mutant of HPr was used carrying on position 46 an alanine that can not be phosphorylated. Electroporation of Ser46Ala-HPr into vesicles did not lead to a reduced uptake of $\left[{ }^{14} \mathrm{C}\right] \mathrm{TMG}$ is the presence of glucose, indicating that phosphorylation of $\mathrm{HPr}$ on residue serine 46 is necessary for inducer exclusion [22].

In both inducer expulsion and inducer exclusion HPr plays a pivotal role. For this reason, the genes $p t s H$ and $p t s I$ encoding the general PTS proteins HPr and enzyme I, respectively, have been cloned from several Gram-positive bacteria including $\mathrm{LAB}$. The genomic organization of these genes shows a remarkable conservation; almost without exception the genes are organized in an operon with $p t s H$ preceding $p t s I$. The same configuration is also found for the $\mathrm{ptsHI}$ genes in L. lactis. Both genes are under the control of one promoter upstream of $p t s H$ and the trans- cription appears to be constitutive (Luesink et al., manuscript in preparation). The functionality of the L. lactis ptsHI gene cluster has been shown by making $p t s H$ and $p t s I$ disruption mutants, that were instrumental in demonstrating that the PTS is the major sugar-uptake system in $L$. lactis. The $p t s H$ mutant was complemented using the $p t s H$ gene under control of a regulated promoter (Luesink et al., manuscript in preparation). This opens possibilities to study, in vivo, the effect of $\mathrm{HPr}$ mutants on the inducer expulsion and inducer exclusion phenomena.

\section{CATABOLITE REPRESSION}

In addition to allosteric control that can result in a very rapid fine tuning of enzymatic reactions, control of gene expression is an alternative but slower process. A well-known example of differential gene expression depending on the nature of the carbon source is catabolite repression (CR). The mechanism by which Grampositive bacteria exert catabolite repression is completely different from that found in Gram-negative enteric bacteria such as Escherichia coli. The two key compounds in the latter process, the regulator CRP and the signal molecule cAMP are respectively not or only in low concentrations present in Gram-positive bacteria. CR in Gram-positive bacteria is a negative regulatory mechanism mediated via the catabolite control protein $\mathrm{A}(\mathrm{CcpA})$ and a cis-acting catabolite responsive element (CRE) located near the transcription start site of genes affected by CR [8]. The first CRE has been identified in the promoter of the alfa-amylase gene of $B$. subtilis [16]. By site-directed mutagenesis a consensus sequence was defined that conformed to the sequence TGWNANCGNTNWCA. An extensive database search showed the presence of CRE boxes near the transcription start of several genes 
involved in carbohydrate metabolism in Gram-positive bacteria including LAB [9].

The CcpA protein that was first identified in B. subtilis contains a helix-turnhelix DNA binding domain in the $\mathrm{NH}_{2}$ terminal part of the protein [8]. CcpA together with $\mathrm{HPr}(\mathrm{Ser}-\mathrm{P})$ and possibly together with early glycolytic intermediates like FDP or glucose-6-P form a complex that is able to bind to CRE boxes $[11,14,17]$. By binding to these CRE boxes this complex prevents or reduces the transcription of these genes. The interaction between CcpA and $\mathrm{HPr}(\mathrm{Ser}-\mathrm{P})$ and the involvement of FDP and glucose-6-P in the binding to CRE boxes links glyco- lytic activity to CcpA-mediated CR [5] (figure 2). Immunological experiments using polyclonal antibodies raised against B. megaterium $\mathrm{CcpA}$ indicated that $\mathrm{CcpA}$ like proteins were present in a great number of Gram-positive bacteria including LAB [12] (table I). After the identification of a possible CcpA like protein in L. lactis an E. coli phage library containing $L$. lactis DNA was screened with the CcpA anti-serum and a positive phage was isolated. Sequence analysis of the insert DNA revealed an open reading frame the sequence of which showed high homo$\log y$ to other CcpA proteins with up to $52 \%$ of identical residues compared to

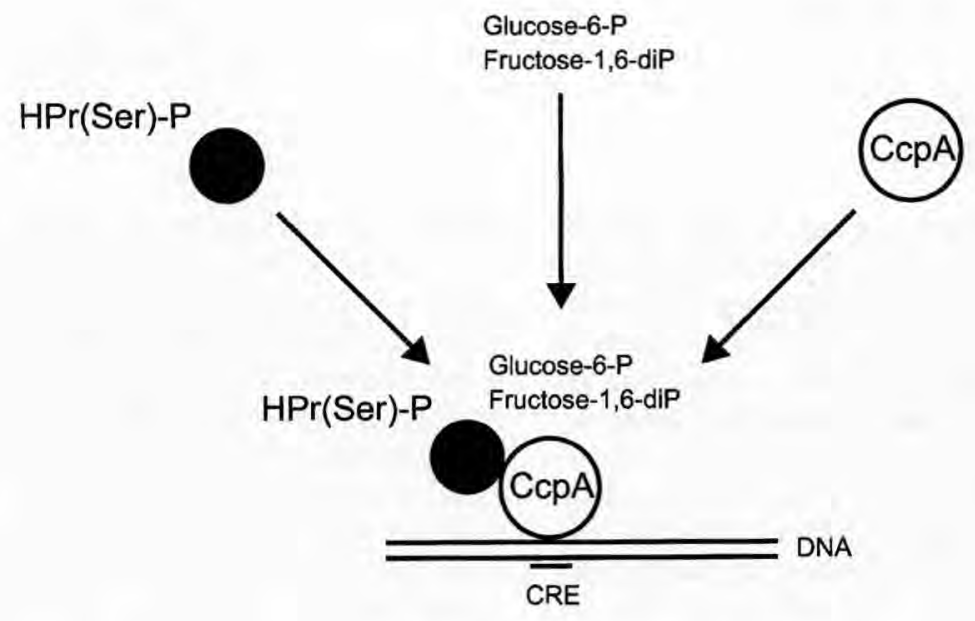

Transcriptional regulation

e.g. Catabolite repression

Figure 2. Proposed model for the regulation of gene expression via CcpA. The serine 46 phosphorylated form of HPr, that occurs when the concentration of FDP increases, is supposed to interact with the transcriptional regulator $\mathrm{CcpA}$. This complex, together with early glycolytic intermediates like glucose-6-P or FDP, can bind to CRE elements found in the promoter region of genes subject to catabolite regulation. By binding to these CRE elements the expression of these genes is affected.

Figure 2. Modèle proposé pour la régulation de l'expression de gènes via $\mathrm{CcpA}$. La forme sérine-46 phosphorylée de HPr, qui est présente lorsque la concentration en FDP augmente, est supposée interagir avec le régulateur transcriptionnel CcpA. Ce complexe, avec les intermédiaires précoces de la glycolyse tels que glucose-6-P ou FDP, peut se lier aux éléments CRE trouvés dans la région du promoteur du gène sujet à la régulation catabolique. Par liaison à ces éléments CRE, l'expression de ces gènes est affectée. 
Table I. An overview of the CcpA-like proteins and their genes from different lactic acid bacteria. Tableau I. Liste des protéines de type CcpA et de leurs gènes dans différentes bactéries lactiques.

\begin{tabular}{|c|c|c|c|c|}
\hline \multicolumn{2}{|c|}{$\begin{array}{l}\text { Immunological } \\
\text { detection }\end{array}$} & \multirow{2}{*}{$\begin{array}{c}\text { Gene } \\
\text { characterized } \\
+\end{array}$} & $\begin{array}{l}\text { Insertional } \\
\text { inactivation }\end{array}$ & Reference \\
\hline Lactococcus lactis & + & & (1 & $\begin{array}{l}\text { (Luesink et al. manuscript } \\
\text { in preparation) }\end{array}$ \\
\hline Leuconostoc lactis & + & $+{ }^{*}$ & & $\begin{array}{l}\text { (Luesink et al. manuscript } \\
\text { in preparation) }\end{array}$ \\
\hline Lactobacillus casei & + & + & + & {$[15]$} \\
\hline Lactobacillus pentosus & + & $+^{*}$ & + & [13] \\
\hline Lactobacillus delbrueckii & & + & & [18] \\
\hline Lactobacillus plantarum & + & & & [12] \\
\hline \multicolumn{2}{|c|}{ Streptococcus thermophilus +} & + & & $\begin{array}{l}\text { (van de Bogaard, } \\
\text { personal communication) }\end{array}$ \\
\hline
\end{tabular}

Lactobacillus casei CcpA (Luesink et al., manuscript in preparation). The chromosomal $\operatorname{cp} A$ gene was disrupted by insertional inactivation. Cell-free extracts of this strain no longer cross-reacted with the CcpA anti-serum indicating that the singlecopy lactococcal $\operatorname{ccpA}$ gene had been disrupted. The $\operatorname{ccpA}$ mutant showed a reduced growth rate on all the carbon sources tested so far (Luesink et al., manuscript in preparation). The reduced growth rate has also been observed in other bacteria and could indicate the involvement of $\mathrm{CcpA}$ in the regulation of some metabolic pathways [10].

In the lactose gene cluster of $L$. lactis a CRE box is located near the transcription start site of the lacA gene encoding a galactose-6-P isomerase. Another CRE box was found in the sucrose gene cluster of $L$. lactis near the transcription start of the $s a c B$ and $s a c A$ genes encoding enzyme II $^{\text {suc }}$ and sucrose-6-P hydrolase, respectively (Luesink et al., manuscript in preparation). The lactose and the sucrose gene clusters are regulated by the operon-specific regulator proteins, LacR and SacR, respectively. After disruption of the lacR and $s a c R$ genes the transcription of the respective gene clusters became constitutive and did not vary significantly in response to the carbon source [21] (Luesink et al., manuscript in preparation). This indicates that CR of these gene clusters is most likely regulated via the concentration of inducer, suggesting that inducer exclusion and inducer expulsion in combination with the operon-specific regulator proteins mediate catabolite repression of these gene clusters and that the general CcpA-CRE mechanism plays a minor role, under the conditions tested.

\section{CONCLUDING REMARKS}

Lactococcus lactis can modulate the intracellular concentration of sugar phosphates via several mechanisms such as inducer expulsion, inducer exclusion and 
catabolite repression. The genes encoding key elements in these processes, HPr and $\mathrm{CcpA}$, have been identified, characterized and mutated. This allows for a further engineering of global control systems ultimately aimed at optimizing carbon fluxes in L. lactis and other LAB.

\section{ACKNOWLEDGMENTS}

We thank M. Kleerebezem, R. Siezen, J. Hugenholtz and J. Wouters for critically reading the manuscript. This work was supported by the European Community Biotech Programme (contract $\mathrm{n}^{\circ} \mathrm{BIO} 2$ CT92-0137 and BIOT-CT-96-04898).

\section{REFERENCES}

[1] Crow V.L., Pritchard G.G., Purification and properties of pyruvate kinase from Streptococcus lactis, Biochim. Biophys. Acta 438 (1976) 90-101.

[2] Crow V.L., Pritchard G.G., Fructose 1,6 diphosphate-activated L-lactate dehydrogenase from Streptococcus lactis; kinetic properties and factors affecting activation, J. Bacteriol. 131 (1977) 82-91.

[3] Deutscher J., Saier M.H, ATP-dependent protein kinase-catalyzed phosphorylation of a seryl residue in $\mathrm{HPr}$, a phosphate carrier protein of the phosphotransferase system in Streptococcus pyogenes, Proc. Natl. Acad. Sci. U.S.A. 80 (1983) 6790-6794.

[4] Deutscher J., Pevec B., Beyreuther K., Kiltz H.H., Hengstenberg W., Streptococcal phosphoenolpyruvate-sugar phosphotransferase system: amino acid sequence and site of ATP-dependent phosphorylation of HPr, Biochemistry 25 (1986) 6543-6551.

[5] Deutscher J., Kuester E., Bergstedt U., Charrier V., Hillen W., Protein kinase-dependent $\mathrm{HPr} / \mathrm{CcpA}$ interaction links glycolytic activity to carbon catabolite repression in Grampositive bacteria, Mol. Microbiol. 15 (1995) 1049-1053.

[6] De Vos W.M., Metabolic engineering of sugar catabolism in lactic acid bacteria. Antonie van Leeuwenhoek 70 (1996) 223-242.
[7] De Vos W.M., Vaughan E.E., Genetics of lactose utilization in lactic acid bacteria, F.E.M.S. Microbiol. Rev, 15 (1994) 217-237.

[8] Henkin T.M., Grundy F.J., Nicholson W.L., Chambliss G.H., Catabolite repression of alpha-amylase gene expression in Bacillus subtilis involves a trans-acting gene product homologous to the Escherichia coli lacl and galR repressors, Mol. Microbiol. 5 (1991) 575-584.

[9] Hueck C.J., Hillen W., Saier M.H. Jr., Analysis of a cis-active sequence mediating catabolite repression in Gram-positive bacteria, Res. Microbiol. 145 (1994) 503-518.

[10] Hueck C.J., Kraus A., Schmiedel D., Hillen W., Cloning, expression and functional analysis of the catabolite control protein CcpA from Bacillus megaterium, Mol. Microbiol. 16 (1995) 855-864.

[11] Kim J.H., Guvener Z.T., Cho J,Y., Chung K.C., Chambliss G.H., Specificity of DNA binding activity of the Bacillus subtilis catabolite control protein CcpA, J. Bacteriol. 177 (1995) 5129-5134.

[12] Kuester E., Luesink E.J., de Vos W.M., Hillen W., Immunological crossreactivity to the catabolite control protein CcpA from Bacillus megaterium is found in many Gram-positive bacteria, FEMS Microbiol. Lett. 139 (1996) 109-115.

[13] Lokman B.C., Heerikhuisen M., Pouwels P.H., Investigation of the role of XylR and $\mathrm{CcpA}$ in the regulation of the Lactobacillus pentosus xylose regulon, Fifth symposium on Lactic acid bacteria, Veldhoven, the Netherlands, 1996, Abstract H14.

[14] Miwa Y., Nagura K., Eguchi S., Fukuda H., Deutscher J., Fujita Y., Catabolite repression of the Bacillus subtilis gnt operon exerted by two catabolite-sensitive elements, Mol. Microbiol. 23 (1997) 1203-1213.

[15] Monedero V., Perez-Martinez G., Cloning and disruption of the cсpA gene in Lactobacillus casei, Fifth symposium on Lactic acid bacteria, Veldhoven, the Netherlands, 1996, Abstract H53.

[16] Nicholson W.L., Park Y.K., Henkin T.M., Won M., Weickert M.J., Gaskell J.A., Chambliss G.H., Catabolite repression-resistant mutations of the Bacillus subtilis alpha-amylase promoter affect transcription levels and are in an operator like sequence, J. Mol. Biol. 198 (1987) 609-618.

[17] Ramseier T.M., Reizer J., Kuester E., Hillen W., Saier M.H., In vitro binding of the CcpA protein of Bacillus megaterium to cis-acting catabolite responsive elements (CREs) of Grampositive bacteria, FEMS Microbiol. Lett. 129 (1995) 207-213. 
[18] Stucky K., Schick J., Klein J.R., Henrich B., Plapp R., Characterization of $p e p R 1$, a gene coding for a potential transcriptional regulator of Lactobacillus delbrueckii supsp. lactis DSM7290, FEMS Microbiol. Lett. 136 (1996) 63-69.

[19] Thompson J., Regulation of sugar transport and metabolism in lactic acid bacteria, FEMS Microbiol. Rev. 46 (1987) 221-231.

[20] Thompson J., Chassy B.M., Intracellular hexose-6-phosphohydrolase from Streptococcus lactis: purification, properties, and function, J. Bacteriol. 156 (1983) 70-80.

[21] Van Rooijen R.J., De Vos W.M., Molecular cloning, transcriptional analysis, and nucleotide sequence of $l a c R$, a gene encoding the repressor of the lactose phosphotransferase system of Lactococcus lactis, J. Biol. Chem. 265 (1990) 18499-18503.

[22] Ye J.J., Reizer J., Cui X., Saier M.H., Inhibition of the phosphoenolpyruvate: lactose phosphotransferase system and activation of a cytoplasmic sugar-phosphate phosphatase in Lactococcus lactis by ATP-dependent metabolite-activated phosphorylation of serine 46 in the phosphocarrier protein HPr, J. Biol. Chem. 269 (1994) 11837-11844.

[23] Ye J.J., Saier M.H., Purification and characterization of a small membrane-associated sugar phosphate phosphatase that is allosterically activated by $\mathrm{HPr}(\operatorname{Ser}(\mathrm{P}))$ of the phosphotransferase in Lactococcus actis, J. Biol. Chem. 270 (1995) 16740-16744. 